\title{
ENVIRONMENTAL SUSTAINABILITY INDICATORS FOR UNIVERSITIES
}

\author{
Laslo Šereš \\ Faculty of Economics in Subotica, University of Novi Sad, \\ Subotica, Republic of Serbia \\ Pere Tumbas \\ Faculty of Economics in Subotica, University of Novi Sad, \\ Subotica, Republic of Serbia \\ Predrag Matković \\ Faculty of Economics in Subotica, University of Novi Sad, \\ Subotica, Republic of Serbia
}

\begin{abstract}
Over the past two decades, many universities have engaged and included the concept of sustainable development into their academic systems. Numerous declarations and charters have been signed and initiatives accepted, providing universities with guidelines or frameworks, and also showing their dedication to include the aspect of sustainability into their business systems. All of this, however, does not secure their successful implementation. To attain a higher responsibility level at universities, it is generally necessary to perform monitoring or assessment of sustainable development. After the introductory considerations, this paper briefly elaborates the most frequently used types of metrics in sustainability assessment. Available results of completed empiric research into sustainable development at 15 universities worldwide, published in separate reports on sustainable development or general annual reports were collected from web pages. These were used for identification, analysis and systematization of sustainability indicators at universities. Only environmental sustainability indicators were chosen as object of detailed observation. Five primary groups of indicators have been established and certain suggestions for future actions have been made, which need to be implemented at universities to attain better sustainable development results at universities in the short run.
\end{abstract}

Key words: university, sustainable university, environmental sustainability, sustainability indicators, environmental sustainability indicators, business processes,

*laslo.seres@ef.uns.ac.rs 


\section{INDIKATORI ODRŽIVOSTI ŽIVOTNE SREDINE NA UNIVERZITETIMA}

Sažetak: Tokom poslednje dve decenije, mnogi univerziteti su angažovali i uključili koncepte održivog razvoja u svoj akademski sistem. Potpisane su brojne deklaracije $i$ povelje, prihvaćene su inicijative, koje obezbeđuju smernice ili radne okvire univerzitetima i ujedno pokazuju njihovu posvećenost da aspekt održivosti uključe u svoj poslovni sistem. Međutim, sve to ne obezbeđuje njegovu uspešnu implementaciju. Da bi nivo odgovornosti na univerzitetima bio viši, neophodno je vršiti monitoring ili ocenu održivog razvoja. U ovom radu se, nakon uvodnog razmatranja koncepta održivog razvoja, ukratko elaboriraju najčešće upotrebljavani tipovi metrika u oceni održivosti. Prikupljeni su putem internet stranica dostupni rezultati realizovanih empirijskih istraživanja održivog razvoja na petnaest univerziteta u svetu, objavljeni u posebnim izveštajima o održivom razvoju ili $u$ opštim godišnjim izveštajima poslovanja. Oni su poslužili za identifikaciju, analizu $i$ sistematizaciju indikatora održivosti na univerzitetima. Za predmet detaljnog posmatranja odabrani su samo indikatori održivosti životne sredine. Utvrđeno je $i$ opisano pet primarnih grupa indikatora $i$ date su određene sugestije za moguće akcije, koje bi bilo neophodno sprovesti na univerzitetima da bi kratkoročno ostvarili bolje rezultate u svom održivom razvoju.

Ključne reči: univerzitet, održivi univerzitet, održivost životne sredine, indikatori održivosti, indikatori održivosti životne sredine, poslovni procesi

\section{INTRODUCTION}

Sustainable development has been one of most been mentioned concepts over the past two decades. As such, it has become an alternative to the dominant socio-economic paradigm (Lozano, 2008). It is highly contemporary, jargonistic, widely used, but, at the same time, denotes different things to different people. Depending on the point of view, it has numerous meanings (Filho, 2011). One of the most popular interpretations is that given by the United Nations. Sustainable development has been defined as development that meets the needs of the present without compromising the ability of future generations to meet their own needs (WCED, 1987).

The concept of sustainable development has also been accepted by universities, and numerous declarations, charters, initiatives and programs have emerged that have influenced the acceptance and development of the concept of sustainable university. The role of the university has, over time, become more and more important, but also more comprehensive and diverse in sustainable development. The business processes of the universities have 

changed substantially and to a greater extent have included some or all of the three constituent dimensions of their sustainable development - the social, economic and environmental sustainability. Defining the goals of universities in sustainable development and the desire to monitor their level of achievement led to the need to identify measure and evaluate sustainability indicators.

After a general interpretation of the contents of the dimensions of sustainable development, the paper presents the possibilities of their integration and mutual interaction, as a condition for the realization of sustainable development. Following this, the concept of a sustainable university is presented, viewed primarily through the prism of the impact of this concept on the mega business processes of the universities. Finally, indicators for measuring environmental sustainability of universities have been identified, analyzed and systematized, following the examples from the annual reports on sustainable development at selected universities in the world. In this way, the aim of the research in this paper was achieved - to get to know the most important indicators of environmental sustainability at universities in the world, in order to make a small step towards the implementation of the concept of sustainable development at universities in Serbia. The identified set of indicators could serve as a starting point for future research to determine the current values of selected indicators at individual universities in Serbia and to compare the achievements in the process of their transformation into sustainable universities. This would provide a basis for defining short-term actions at universities in order to achieve better results in the sustainable development of Serbian universities.

\section{THEORETICAL BACKGROUND}

Despite the broad use, the 'sustainability' remains an open concept with myriad interpretetions and context-specific understanding (Purvis, Mao and Robinson 2019). In the description of the term many conceptions have been used interchangeably: pillars, dimensions, components, aspects, stool legs, perspectives and others. The three pillar concept of sustainability, represented by three intersecting circles with overall sustainability at the centre, was selected as the basis for theoretical considerations of this term in the paper.

Visual presentations of the concept have appeared for better understanding between discourse participants (Lozano, 2008). The most frequently used ones are: (a) representation in the form of Venn diagram, that is, three overlapping circles, where intersections point to commotion between different aspects of sustainability; (b) presentation in the form of three 
98 | ENVIRONMENTAL SUSTAINABILITY INDICATORS FOR UNIVERSITIES

concentric circles, where the inner circle represents economic aspects, the next circle is for social aspects, and the outer circle represents environmental aspect of sustainable development; and (c) representation of dynamic equilibrium, where elements of sustainability are viewed in equilibrium as independent and separate. These graphic representations, illustrated in Figure 1, were of much use in terms or raising awareness and involvement of public into consideration of the concept of sustainability.
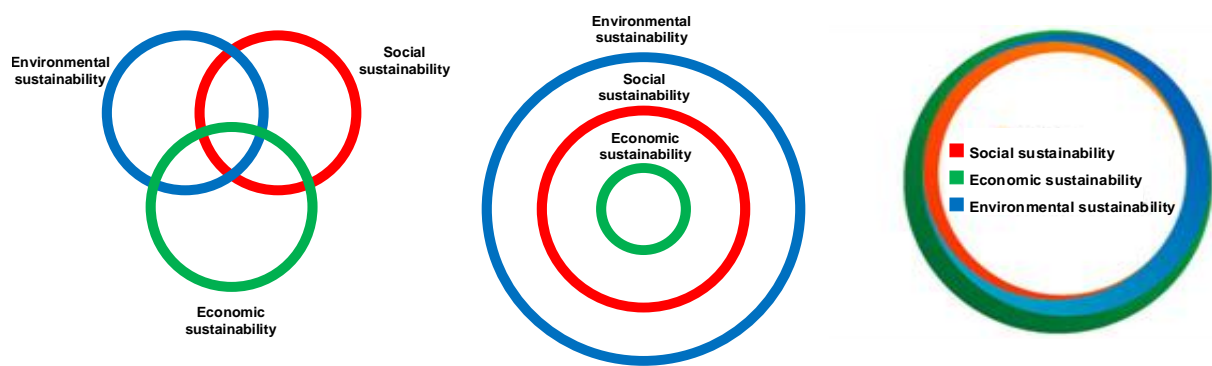

Figure 1. Visual representations of the concept of sustainable development Note. Based on Lozano, R. (2008). Envisioning sustainability three-dimensionally. Journal of Cleaner Production, 16, 1777-1785.

Therefore, the concept of sustainable development rests on three pillars, that is: environmental sustainability, economic sustainability and social sustainability. In most cases, these constituents of sustainable development are presented as shown in Figure 2. If any of the pillars of sustainability is weak, then the whole system is unsustainable.

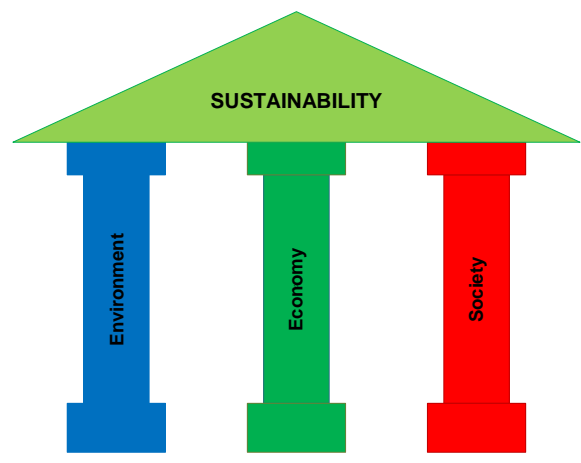

Figure 2. Constituents of the sustainable development concept

Note. Based on Purvis, B., Mao, Y., and Robinson, D. (2019). Three pillars of sustainability: in search of conceptual origins. Sustainability Science, 14, 681-695.

Sustainable development should integrate social, economic and environmental sustainability and use them to make development sustainable (Goodland, 1995). Environmental sustainability, often termed ecological 
Laslo Šereš, Pere Tumbas, Predrag Matković | 99 sustainability, pertains to and includes integrity of the eco-system and care of its capacity and biodiversity. It also includes care of preserving quality of air, water and soil, more efficient use and reuse of natural resources and energy. Economic sustainability pertains to economic growth and development, and, above all, pertains to seeking responses to the challenges of achieving competitive advantages through a more efficient and productive utilisation of available resources, parallelly appreciating the need to remove or minimize environmental impact. Social sustainability involves the introduction of the principles of fairness and meeting the needs of the majority of the earth's inhabitants in the process of sustainable development. Sustainable social development is an integrated process of building the ability of individuals aimed at achieving their equality and participation in social life. Also, social sustainability includes promoting integration of society, achieving education and health care available to all, crime prevention and tackling all negative phenomena, democratization of all areas of social life, change in needs and consumer habits. In addition to these, considerations on sustainable development often include additional pillars: cultural sustainability and spatial sustainability. Figure 3 illustrates interaction of the three primary aspects of sustainability.

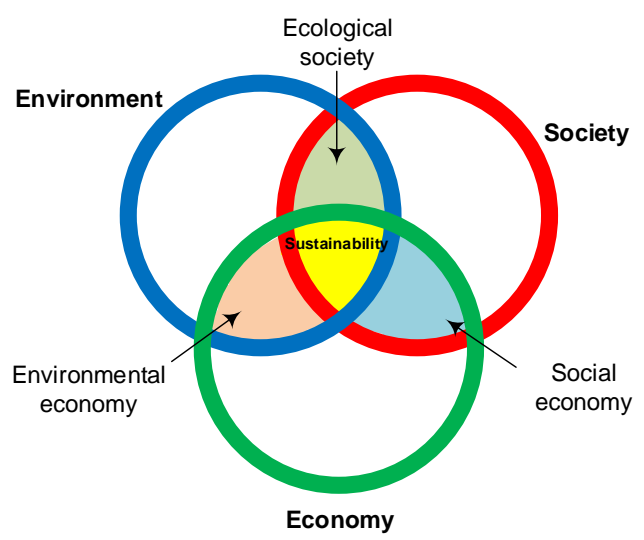

Figure 3. Interaction of the aspects of sustainable development

Note. Based on Sikdar, S. K. (2003). Sustainable development and sustainability metrics. AIChE journal, 49(8), 1928-1932.

There are many ways for universities to be able and obliged to be involved in sustainable development, related to management, planning, development, education, research, operational activities, community action, acquisition, transport, construction, adaptation etc. As scientific and educational institutions, universities play an exceptionally significant role in not only 
100 | ENVIRONMENTAL SUSTAINABILITY INDICATORS FOR UNIVERSITIES

promotion and development but also application of the concept of sustainable development.

Table 1

Overview of key documents dealing with sustainable development of universities

\begin{tabular}{|c|c|c|}
\hline Year & Declaration/Charter/Initiative/Partnership & $\begin{array}{c}\text { Area of } \\
\text { application }\end{array}$ \\
\hline 1977 & Tbilisi Declaration, UNESCO & Global \\
\hline 1988 & Magna Charta of European Universities. & $\begin{array}{l}\text { Regional- } \\
\text { Europe }\end{array}$ \\
\hline 1990 & Talloires Declaration, University Leaders for Sustainable Future. & Global \\
\hline 1991 & $\begin{array}{l}\text { Halifax Declaration, Conference on University Action for } \\
\text { Sustainable Development }\end{array}$ & Global \\
\hline 1993 & $\begin{array}{l}\text { Kyoto Declaration on Sustainable Development, International } \\
\text { Association of Universities. }\end{array}$ & Global \\
\hline 1993 & $\begin{array}{l}\text { Swansea Declaration, Association of Australian Government } \\
\text { Universities }\end{array}$ & Global \\
\hline 1994 & $\begin{array}{l}\text { Copernicus University Charter on Sustainable Development, } \\
\text { Association of European Universities. }\end{array}$ & $\begin{array}{l}\text { Regional- } \\
\text { Europe }\end{array}$ \\
\hline 1998 & World Declaration for Higher Education, UNESCO & Global \\
\hline 2000 & $\begin{array}{l}\text { Towards a Century of Cooperation - Internationalization of Higher } \\
\text { Education, Global Higher Education for Sustainability Partnership } \\
\text { (GHESP). }\end{array}$ & Global \\
\hline 2001 & $\begin{array}{l}\text { Lüneburg Declaration, Higher Education for Sustainable } \\
\text { Partnership. }\end{array}$ & Global \\
\hline 2002 & $\begin{array}{l}\text { Ubuntu Declaration, Education and Science and Technology for } \\
\text { Sustainable Development. }\end{array}$ & Global \\
\hline 2002 & Johannesburg Declaration, United Nations & Global \\
\hline 2005 & $\begin{array}{l}\text { Graz Declaration on Committing Universities to Sustainable } \\
\text { Development }\end{array}$ & Global \\
\hline 2005 & $\begin{array}{l}\text { Bologna Declaration - Bergen Communique, Ministers of } \\
\text { Education in Europe }\end{array}$ & $\begin{array}{l}\text { Regional- } \\
\text { Europe }\end{array}$ \\
\hline 2006 & $\begin{array}{l}\text { American College and University Presidents' Climate } \\
\text { Commitment }\end{array}$ & $\begin{array}{l}\text { Regional- } \\
\text { USA }\end{array}$ \\
\hline 2008 & $\begin{array}{l}\text { Declaration of the Regional Conference on Higher Education in } \\
\text { Latin America and the Caribbean }\end{array}$ & Regional \\
\hline 2008 & Sapporo Sustainability Declaration, G8 University Network. & Global \\
\hline 2009 & $\begin{array}{l}\text { Abuja Declaration on Sustainable Development in Africa: The role } \\
\text { of higher education in Sustainable Development }\end{array}$ & Global \\
\hline 2009 & $\begin{array}{l}\text { Bonn Declaration, World Conference on Higher Education, } \\
\text { UNESCO }\end{array}$ & Global \\
\hline 2009 & $\begin{array}{l}\text { Turin Declaration on Education and Research for Sustainable and } \\
\text { Responsible Development, G8 University Network. }\end{array}$ & Global \\
\hline 2012 & $\begin{array}{l}\text { Rio+20 Declaration, Treaty, Higher Education Sustainability } \\
\text { Initiative }\end{array}$ & Global \\
\hline 2014 & Aichi-Nagoya Declaration on Education for Sustainable Develop. & Global \\
\hline 2015 & Kuala Lumpur Declaration on Higher Education & $\begin{array}{l}\text { Regional- } \\
\text { ASEAN }\end{array}$ \\
\hline
\end{tabular}

Note. Based on Filho (2011); Lozano et al, (2013); Lozano et al, (2015). 


\section{SUSTAINABILITY INDICATORS}

Two groups of metrics in the system of development show the state and performance of a system. These metrics are usually termed as indicators. Indicators showing the state of a system are content indicators, whereas indicators measuring behaviour of a system are performance indicators.

When choosing indicators to measure the system sustainability, one must make sure that they are simple and clearly focused. To keep them simple, the number of indicators should be limited, and the manner of calculating them should be transparent. To be clearly focused, however, indicators should point to items and trends obviously relevant for sustainability, and be sensitive, that is, signalize progress or absence thereof.

Undoubtedly, other principles must also be taken into account when selecting indicators. Thus, they need to be relevant and meaningful, scientifically founded, widely accepted, sensitive to change, based on exact and available data, comprehensible, unambiguous, media receptive, etc.

Normally, performance indicators are the research subject, as researchers primarily measure the improvement of the three aspects of sustainability to improve the characteristics of system sustainability. Therefore, we initially differentiate between economic indicators, social indicators and environmental indicators, measuring a single aspect of the system. Hence, these are refered to as the unidimensional indicators. There are, however, attempts to use bidimensional indicators to measure indicators of ecological efficiency, socio-environmental indicators and socio-economic indicators. Finally, tridimentional indicators emerge through interaction of all three aspects of system sustainability, which are the true sustainability indicators. The position of all seven groups of indicators is illustrated in Figure 4.

\section{ENVIRONMENTAL SUSTAINABILITY INDICATORS AT UNIVERSITIES}

Environmental or ecological sustainability is a set of limitations of the following four main activities regulating the scope of economic system (systems of production, resource allocation, exchange and distribution of goods and services in society): use of renewable and non-renewable sources on the one hand, and pollution and waste assimilation on the other (Goodland, 1995).

Identification, analysis and systematization of environmental sustainability indicators in this paper was done based on results collected from reports on sustainable development at selected universities listed in Table 2. 


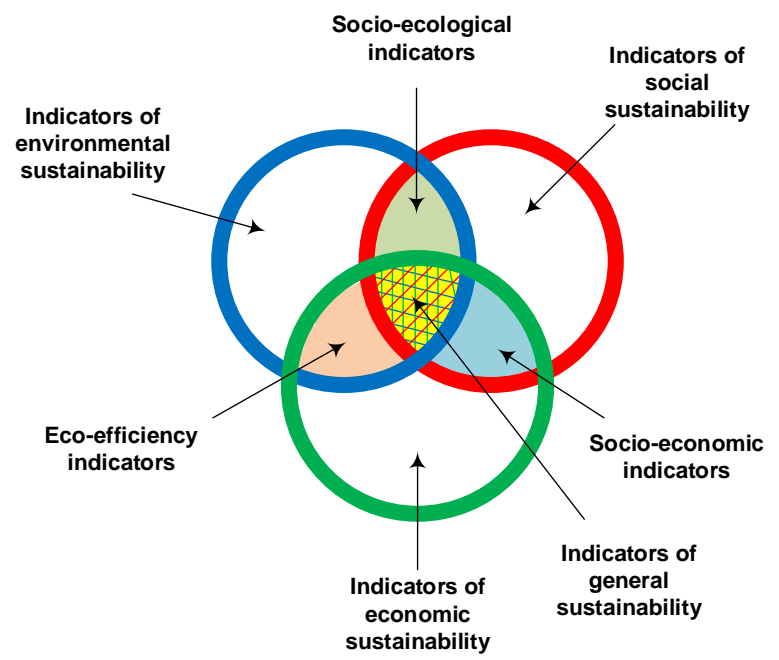

Figure 4. Presentation of groups of system sustainability indicators

Note. Based on Sikdar, S. K. (2003). Sustainable development and sustainability metrics. AIChE journal, 49(8), 1928-1932.

Table 2

Overview of used reports on sustainable development at universities

\begin{tabular}{|c|c|c|}
\hline State & Name of university & Source reference \\
\hline \multirow{4}{*}{ The US } & Harvard University & (Harvard University, 2015) \\
\hline & Berkeley University & (Berkeley University, 2014) \\
\hline & Boston University & (Boston University, 2014) \\
\hline & University of Virginia & (University of Virginia, 2015) \\
\hline \multirow{3}{*}{ The UK } & University of Oxford & (University of Oxford, 2015) \\
\hline & University of Liverpool & (University of Liverpool, 2014) \\
\hline & City University London & (City University, 2014) \\
\hline Sweden & University of Gothenburg & (University of Gothenburg, 2015) \\
\hline \multirow{2}{*}{ Canada } & University of British Columbia & (University of British Columbia, 2014) \\
\hline & University of Calgary & (University of Calgary, 2013) \\
\hline \multirow{3}{*}{ Australia } & University of Queensland & (University of Queensland, 2014) \\
\hline & Monash University & (Monash University, 2014) \\
\hline & Deakin University & (Deakin University, 2014) \\
\hline Belgium & Ghent University & (Ghent University, 2013) \\
\hline Norway & University of Oslo & (Faghihimani, 2010) \\
\hline
\end{tabular}

Note. Created by the authors.

The research was done on a selected, relatively small sample of universities, but the achieved results make it possible for positive practices and experiences of fifteen respectable universities worldwide to be transferred and used in the process of developing other systems of sustainability indicators. More than 120 indicators, 50 of which are environmental 
Laslo Šereš, Pere Tumbas, Predrag Matković | 103 sustainability indicators, were identified. To systematize them, mega business processes of universities were analysed, as follows: planning and management processes, education processes, research processes and support processes (Petkovics, Tumbas, Matkovic and Baracskai 2014). As shown in Figure 5 five groups of indicators were derived by analysing environmental sustainability indicators. These are: environmental indicators of activities that comprise planning and management processes, environmental indicators of activities of the education processes, environmental indicators of activities of the research processes, environmental indicators of operational activities of the support processes and environmental indicators of other activities of the support processes.

Environmental indicators of activities of planning and management process are indicators referring to environmental strategy, principles and policies; institutionally adopted declarations and resolutions; strategic approach and action plan of universities; position of employees in sustainable development and their organizational allocation at the university; annual reporting on sustainable development.

In addition to these primary criteria, this group of indicators also includes those related to participation of student representatives in university committees for sustainable development; internal rewards and awards to employees, students and departments excelling and most efficient in "green" behaviour at universities; student tariffs; implemented revisions of sustainable development etc.

Environmental indicators of education process refer to the opportunity to learn contents related to environmental sustainability. These are indicators related to availability of study programs in the area of environmental sustainability; availability and level of inclusion of sustainability contents in interdisciplinary and multidisciplinary study programs, e.g. environmental sustainability in law, economics, engineering, medicine, education, politics etc.; the issue of climate change. In addition to these, indicators of special significance are those related to brief and intense courses for students; opportunity to acquire certificates; opportunity for electronic and lifelong learning of contents of sustainable development.

Environmental indicators of the activities of the research process are also of high importance, such as research capacities (centres and/or universities) and their project and research activities in the sphere of environment are assessed through them. A separate focus of observation are forms of co-operation (coordination, co-operation and collaboration) between university centres and/or institutes, as well as with businesses and industry. 


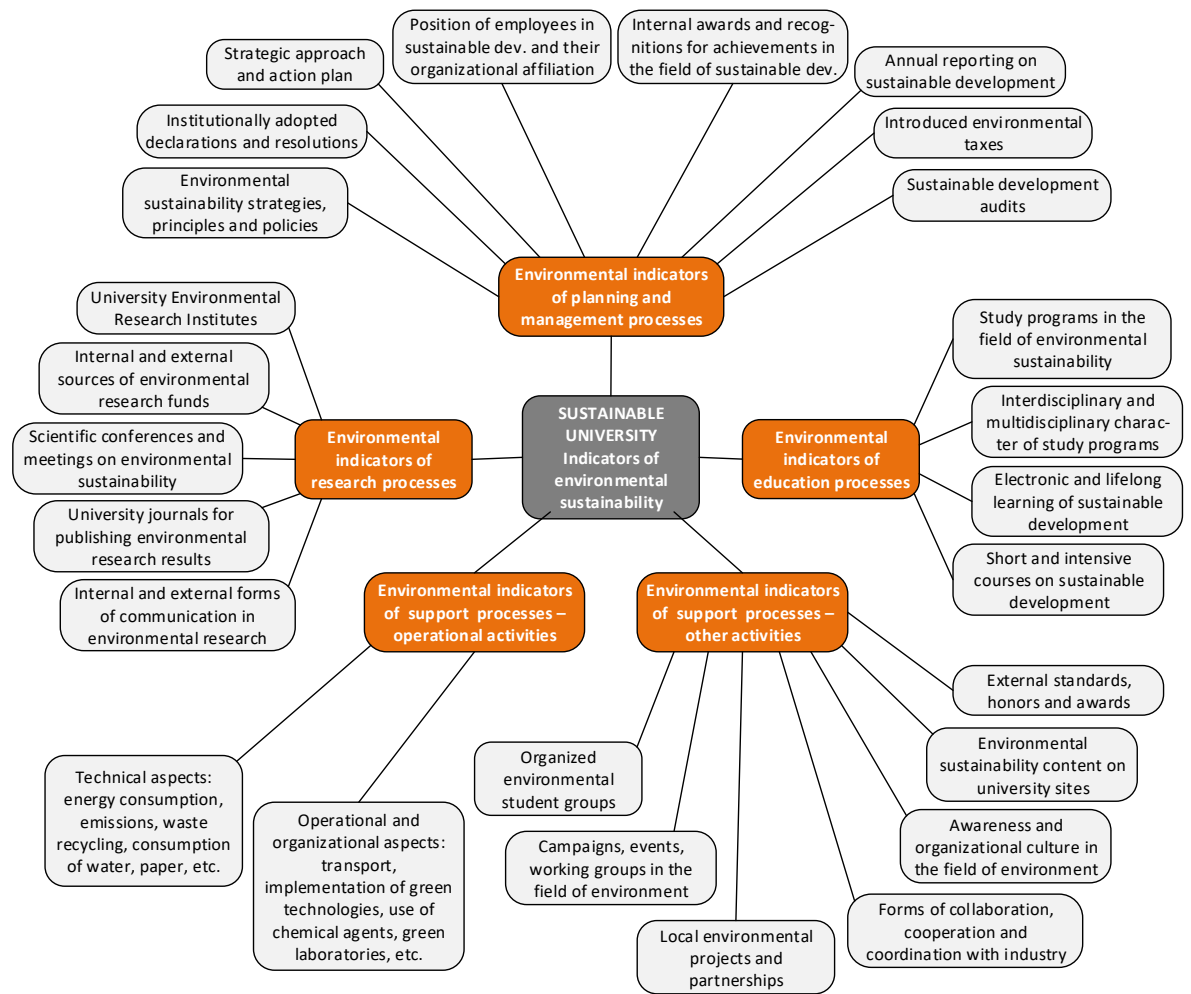

Figure 5. Critical areas of particular groups of environmental indicators at universities

Note. Created by the authors.

Various forms of co-operation with industry, where it finances joint research processes, sponsors the development of innovative products in university centres and/or institutes, sponsors student research on environmental sustainability, etc. Also, various forms of co-operation where the university organizes work meetings, seminars, training for persons from industry. This group includes indicators related to internal and external donations to individuals or centres on projects where the research subject is environmental sustainability. They analyse sources of funding from government institutions, international networks and foundations, local governments, business corporations, business organizations and individuals. At the same time, indicators also include analysis of communication of university centres on institutional, national or international level. Finally, the indicators of this group also refer to availability of university scientific journals for publishing results of scientific or expert research from the area of environmental sustainability, as well as organizing expert conferences, scientific conventions, symposiums and round tables organized by universities in this area. 
The environmental indicators of operational activities of the support process are the most numerous. They include indicators related to the technical aspects of work of universities and indicators focused on activities in the area of environmental sustainability. The former refer to energy, emission of harmful gases and carbon, waste recycling, university buildings, acquisition (purchase) of environmentally friendly products, water, food and restaurants, paper, accommodation facilities (student dormitories). In addition to these, a special focus of analysis is on the latter group, referring to processes of the system of management of sustainable development at universities, preservation and reuse of resources; transport; implementation of innovation and new technologies at universities; use of chemicals at universities; green laboratories etc.

The last group of environmental indicators pertains to other activities of the process of support at universities. It comprises a large number of very different indicators pertaining to organizing student groups for landscaping campuses, raising awareness and participation in community work; organizing various events such as campaigns, task forces, events, artistic or cultural events, etc.; implementation of local projects; partnerships with the local community on joint financing, investment, support for achieving goals in the area of environmental sustainability; creating web content on university media related to environmental sustainability; international visibility of universities in relation to content on sustainable development; introducing external standards and awareness; raising awareness and bringing change in the organizational culture at universities.

Without establishing an appropriate system of management, dedication of universities to sustainable development inevitably remains on declarative level. Bearing in mind that there is no management without measurement, measuring performance in the field of sustainable development appears as a prerequisite for assessing the success of efforts of a sustainable university. To measure performance, it is necessary to define a set of indicators for various areas identified as critical factors of implementation of the concept of sustainable development.

Defining a high-quality set of indicators for any area requires certain expertise in the pertinent area. The defined indicators must be precisely described and related to specific activities, events and rules of aggregation. Usually, it is possible to define a large number of indicators, both simple and complex, by putting other indicators into relation based on a relatively small number of facts (for instance, various share indicators, growth indicators, derived indicators etc.). 
106 | ENVIRONMENTAL SUSTAINABILITY INDICATORS FOR UNIVERSITIES

The generic sets of indicators for all the groups listed in Figure 5 are presented below (Table 3). These generic sets may serve as a good starting point in the domain of implementation of concepts and taking specific actions aimed at environmental sustainability.

Most of the greenhouse gases on campus result from using steam (coal, wood, fuel oil) and electric power. By applying appropriate standards, it is possible to express (calculate) the amount of consumed energy which directly or indirectly generated carbon dioxide, where this depends to a high extent on external factors as well, for instance structure of power plants (thermo, hydro, wind, bio...) from which the electric power distributors provide energy. This is not the only example when external factors can make a significant impact on achievements of universities in the area of environmental sustainability. As an additional example, we can mention situations when improvement in energy and other efficiency is significantly aggravated by the fact that the university uses historic buildings listed as cultural monuments, or when the university campus is located in the centre of the town, leaving little space for larger green surfaces (Basso, Cardin, Giacometti and Mio Ch., 2017). These circumstances somehow limit the potentials of certain universities in the area of achievements in the domain of environmental sustainability, so eliminating the impact of these aggravating objective factors is a great challenge for various environmental categorizations and ranking universities.

The above mentioned generic set of key indicators is suitable for deriving new indicators, for instance, establishing relation between energy consumption and number of campus population. It is, however, much more important to emphasise that, for the purpose of efficient measurement and management of environmental sustainability of development of universities, it is necessary to define a far larger number of indicators. This is also inevitable, to say the least, due to the fact that a vast majority of key indicators is derived based on values of numerous individual indicators. Let us take the example of the key indicator Amount of Generated Carbon Dioxide: it has already been mentioned that most emissions of harmful gases originate from the consumption of electric and steam power, but these are not the only sources of emission. A more precise calculation of the equivalent of generated harmful gases requires defining additional indicators related to: business travel of employees (primarily by airplane); fugitive emissions - cooling; commuting; arrival/departure of students to/from educational activities; the university's fleet, etc.

\section{Table 3}

Key environmental indicators of university mega processes 


\begin{tabular}{|c|c|c|}
\hline $\begin{array}{c}\text { Activities of } \\
\text { university } \\
\text { mega } \\
\text { processes }\end{array}$ & Name of key environmental indicator & Measure unit \\
\hline \multirow{8}{*}{$\begin{array}{l}\text { Activities of } \\
\text { planning and } \\
\text { management } \\
\text { processes }\end{array}$} & $\begin{array}{l}\text { Existence of strategic approach and plan of activities aimed } \\
\text { at environmental sustainability }\end{array}$ & $\begin{array}{l}\text { Qualitative } \\
\text { assessment }\end{array}$ \\
\hline & $\begin{array}{l}\text { Share of budget funds channelled to activities related to } \\
\text { environmental sustainability }\end{array}$ & $\%$ \\
\hline & $\begin{array}{l}\text { Number of employees whose activities are primarily related } \\
\text { to environmental sustainability }\end{array}$ & Number \\
\hline & $\begin{array}{l}\text { Conscience and organizational culture of university } \\
\text { employees from the aspect of environmental preservation }\end{array}$ & $\begin{array}{l}\text { Qualitative } \\
\text { assessment }\end{array}$ \\
\hline & Policy of "green" buildings (increasing energy efficiency) & $\begin{array}{l}\text { Qualitative } \\
\text { assessment }\end{array}$ \\
\hline & Policy of reducing the use of paper and plastic on campus & $\begin{array}{l}\text { Qualitative } \\
\text { assessment }\end{array}$ \\
\hline & Policy of pedestrian and cycling zones on campus & $\begin{array}{l}\text { Qualitative } \\
\text { assessment }\end{array}$ \\
\hline & $\begin{array}{l}\text { Policy of rewarding achievements in the area of } \\
\text { environmental sustainability }\end{array}$ & $\begin{array}{l}\text { Qualitative } \\
\text { assessment }\end{array}$ \\
\hline \multirow{5}{*}{$\begin{array}{l}\text { Activities of } \\
\text { education } \\
\text { processes }\end{array}$} & $\begin{array}{l}\text { Number of study programs in the area of environmental } \\
\text { sustainability }\end{array}$ & Number \\
\hline & $\begin{array}{l}\text { Number of multidisciplinary and interdisciplinary study } \\
\text { programs }\end{array}$ & Number \\
\hline & $\begin{array}{l}\text { Number of disciplines/courses related to environmental } \\
\text { sustainability }\end{array}$ & Number \\
\hline & $\begin{array}{l}\text { Representation of contents related to environmental } \\
\text { sustainability on all three study levels }\end{array}$ & $\begin{array}{l}\text { Qualitative } \\
\text { assessment }\end{array}$ \\
\hline & Number of courses related to environmental sustainability & Number \\
\hline \multirow{6}{*}{$\begin{array}{l}\text { Activities of } \\
\text { research } \\
\text { processes }\end{array}$} & $\begin{array}{l}\text { Number of projects/studies in the area of environmental } \\
\text { sustainability }\end{array}$ & Number \\
\hline & $\begin{array}{l}\text { Amount of funds allocated for research in the area of } \\
\text { environment }\end{array}$ & $\begin{array}{l}\text { Monetary } \\
\text { units }\end{array}$ \\
\hline & Share of external funding sources in environmental research & $\%$ \\
\hline & Number of patents related to environmental sustainability & Number \\
\hline & $\begin{array}{l}\text { Number of publications related to environmental } \\
\text { sustainability }\end{array}$ & Number \\
\hline & $\begin{array}{l}\text { Number of conferences with topics related to environmental } \\
\text { sustainability }\end{array}$ & Number \\
\hline \multirow{6}{*}{$\begin{array}{l}\text { Operational } \\
\text { activities of } \\
\text { support } \\
\text { processes }\end{array}$} & \multicolumn{2}{|l|}{ Energy } \\
\hline & Power consumption & $\mathrm{kWh}$ \\
\hline & Steam consumption & MMBtu \\
\hline & Natural gas consumption & MMBtu \\
\hline & Amount of generated carbon monoxide & Metric tons \\
\hline & Share of high energy efficiency devices & $\%$ \\
\hline $\begin{array}{c}\text { Activities of } \\
\text { university } \\
\text { mega } \\
\text { processes }\end{array}$ & Name of key environmental indicator & $\begin{array}{l}\text { Measure } \\
\text { unit }\end{array}$ \\
\hline
\end{tabular}

SCHOOL OF BUSINESS, 2/2019, 95-112 


\begin{tabular}{|c|c|c|}
\hline & Water consumption & Million lit. \\
\hline & Generated waste water & Million lit. \\
\hline & Share of industrial water in total consumption & $\%$ \\
\hline & Share of devices with efficient utilization of used water & $\%$ \\
\hline & Waste & \\
\hline & Generated waste (landfill waste) & Tons \\
\hline & Share of recycled toxic waste & $\%$ \\
\hline & Selective waste collection & $\begin{array}{l}\text { Qualitative } \\
\text { assessment }\end{array}$ \\
\hline & Organic waste treatment & $\begin{array}{l}\text { Qualitative } \\
\text { assessment }\end{array}$ \\
\hline & Inorganic waste treatment & $\begin{array}{l}\text { Qualitative } \\
\text { assessment }\end{array}$ \\
\hline & Transport & \\
\hline & Share of persons coming to campus by car & $\%$ \\
\hline & Share of persons coming to campus by car alone & $\%$ \\
\hline & Share of students coming to campus by car & $\%$ \\
\hline & Share of students walking or cycling & $\%$ \\
\hline & Infrastructure & \\
\hline & $\begin{array}{l}\text { Space in relation to population of campus (staff and } \\
\text { students) }\end{array}$ & $\mathrm{m}^{2}$ \\
\hline & Share of green surfaces on campus & $\%$ \\
\hline & Share of surfaces on campus covered with forest vegetation & $\%$ \\
\hline & Share of buildings with energy efficiency certificate & $\%$ \\
\hline & $\begin{array}{l}\text { Organized student groups in the area of environmental } \\
\text { sustainability }\end{array}$ & Number \\
\hline & $\begin{array}{l}\text { Number of (working) actions in the area of environmental } \\
\text { sustainability }\end{array}$ & Number \\
\hline & Number of events promoting environmental sustainability & Number \\
\hline Other & $\begin{array}{l}\text { Representation of content in the area of environment on } \\
\text { university sites }\end{array}$ & $\begin{array}{l}\text { Qualitative } \\
\text { assessment }\end{array}$ \\
\hline $\begin{array}{l}\text { actuvines of } \\
\text { support }\end{array}$ & $\begin{array}{l}\text { Cooperation with local community in environmental } \\
\text { sustainability activities }\end{array}$ & $\begin{array}{l}\text { Qualitative } \\
\text { assessment }\end{array}$ \\
\hline & $\begin{array}{l}\text { Cooperation with industry aimed at environmental } \\
\text { sustainability }\end{array}$ & $\begin{array}{l}\text { Qualitative } \\
\text { assessment }\end{array}$ \\
\hline & $\begin{array}{l}\text { Number of external awards for achievements in the area of } \\
\text { environmental sustainability }\end{array}$ & Number \\
\hline
\end{tabular}

Note. Created by the authors.

It is noticeable that the offered set of key environmental indicators include a number of those in whose case qualitative assessment appears to be the only way of measuring, i.e. assessing performance in this area. Systematic measurement of values of key performance indicators is a special challenge for all universities (Alghamdi, den Heijer and de Jonge, 2017). It would be ideal if all required data for measuring the value of indicators could be found in the existing, i.e. available information systems at the university. Practice, however, shows that, as a rule, these systems provide only a limited set of data, and that the so-called "white holes" in data (i.e. differences between the required and the actually available data in a system) are fairly large. 
Subsequent upgrade of the existing information systems can result in gradual reduction of this gap, but this is a time-consuming and demanding process. When doing this, one must bear in mind that a significant part of data required for measuring performance in the field of environmental sustainability (especially in the group of activities of planning and managing process) has the character of qualitative data, and, as such, they must be gathered by applying techniques of qualitative assessment (questionnaires, interviews etc.), where it is more than desirable to perform this assessment electronically.

\section{CONCLUSION}

By identifying, analysing and systematising environmental sustainability indicators at fifteen selected universities worldwide, a small step has been made towards implementation of sustainable development of universities in Serbia. The available annual reports of selected universities, covering and showing environmental sustainability indicators were used to identify the most significant indicators of their sustainable development as the initial step. Subsequently, in further research. They will be used to benchmark the universities in Serbia.

When the indicators were only identified and thoroughly analysed, the authors recognized the possible short-term actions that need to be realized at universities to achieve better results of individual indicators. These are actions of general character, not related to any group of presented indicators of university mega processes, also recommended by other authors in their research on sustainable development, seen as challenges in the area of sustainable development of universities (Filho, 2011). These are:

- the need to interpret more widely the concept of sustainability at universities, which above all should contribute to a more intense inclusion of individuals rather than organizations themselves;

- the need to translate and interpret the concept of sustainability at universities to a variety of audiences in a variety of ways, in various national environments;

- the need to operationalize sustainability at universities, that is, produce numerous publications, reports and documents, which would contribute to the theoretic aspect, and to initiate numerous projects that would cover the empirical aspect; and

- the need to raise the level of support to sustainable development at universities in such a way as to especially potentiate the indicators showing long-term tendencies in the area of sustainability.

The generic set of key environmental indicators presented in this paper may serve as a basis for building reference systems of environmental indicators of SCHOOL OF BUSINESS, 2/2019, 95-112 
110 | ENVIRONMENTAL SUSTAINABILITY INDICATORS FOR UNIVERSITIES

specific universities. In this, the key performance indicators feature only as the top of the pyramid and must be supported by a broad pallet of performance indicators as a basis for calculating the values of key indicators. The paper points out that the environment may appear as a limiting factor in terms of performance of universities in the area of sustainable development from the aspect of environment. Differences in external factors may aggravate objective comparison of environmental performance of universities, but, at the same time, this cannot be an excuse or reason for universities not to make an effort to achieve as much as possible in view of the objective circumstances of their functioning.

The paper also provides a brief overview of the objective difficulties appearing when collecting data required for measuring and assessing environmental sustainability of development of universities, with a note that the scarcity of the (currently) available data should not be an obstacle to the implementation of the system of monitoring and enhancing universities' performance in the area of environmental sustainability.

\section{REFERENCES}

Alghamdi, N., den Heijer, A., \& de Jonge, H. (2017). Assessment tools' indicators for sustainability in universities: an analytical overview. International Journal of Sustainability in Higher Education, 18(1), 84-115.

Basso, A., Cardin, M., Giacometti, A., \& Mio Ch. (2017). Sustainability indicators for university ranking. Ca' Foscari University of Venice, No. 18/WP/2017, ISSN: 1827-3580. Retrieved from http://www.unive.it/media/allegato/DIP/Economia/Working_papers/ Working_papers_2017/WP_DSE_basso_cardin_giacometti_mio_18_1 7.pdf

Berkeley University (2014). The 2014 Sustainability Report. Retrieved from http://sustainability.berkeley.edu/reports

Boston University (2014). Sustainability Report. Retrieved from http://www.bu.edu/sustainability/files/2015/06/BU-SustainabilityReport-14-06-03-v01.pdf

City University London (2014). Sustainability Annual Report 2013/14. Retrieved from https://www.city.ac.uk/data/assets/pdf_file/0009/242739/AnnualSustainability-Report-2013-14-final.pdf

Deakin University (2014). Sustainability Report. Retrieved from https://www.deakin.edu.au/_data/assets/pdf_file/0010/392275/Sustai nability-Report-2014-Full.pdf 
Laslo Šereš, Pere Tumbas, Predrag Matković | 111

Faghihimani, M. (2010). Best green university practice. Universitetet in Oslo. Retrieved from http://www.uio.no/english/foremployees/employment/greenuio/projects/

Filho, W.L. (2011). About the Role of Universities and Their Contribution to Sustainable Development. Higher Education Policy, 24, 427-438.

Ghent University (2013). Sustainability report by Ghent University 2013. Retrieved from https://www.ugent.be/en/ghentuniv/healthandsafety/sustainabilityreport.pdf

Goodland, R. (1995). The Concept of Environmental Sustainability. Annual Review of Ecology and Systematics, 26, 1-24.

Harvard University (2015). Harvard Sustainability Report 2015. Retrieved from http://report.green.harvard.edu/

Lozano, R. (2008). Envisioning sustainability three-dimensionally. Journal of Cleaner Production, 16, 1777-1785.

Lozano, R., Lukman, R., Lozano, F.J., Huisingh, D., \& Lambrechts, W. (2013). Declarations for sustainability in higher education: becoming better leaders, through addressing the university system. Journal of Cleaner Production, 48, 10-19.

Lozano, R., Ceulemans, K., Alonso-Almeida, M., Huisingh, D., Lozano, F. J., Waas, T. \& Hugé, J. (2015). A review of commitment and implementation of sustainable development in higher education: results from a worldwide survey. Journal of Cleaner Production, 108, $1-18$

Monash University (2014). Annual Report 2014. Retrieved from https://www.monash.edu/_data/assets/pdf_file/0003/179715/annualreport-2014.pdf

Petkovics, I., Tumbas, P., Matkovic, P. \& Baracskai, Z. (2014). Cloud Computing Support to University Business Processes in External Collaboration. Acta Polytechnica Hungarica, 11(3), 181-200.

Purvis, B., Mao, Y., Robinson, D. (2019). Three pillars of sustainability: in search of conceptual origins. Sustainability Science, 14, 681-695.

Sikdar, S. K. (2003). Sustainable development and sustainability metrics. AIChE journal, 49(8), 1928-1932. 
112 | ENVIRONMENTAL SUSTAINABILITY INDICATORS FOR UNIVERSITIES

University of British Columbia (2014). Annual Sustainability Report 2013/14. Retrieved from https://sustain.ubc.ca/sites/sustain.ubc.ca/files/uploads/CampusSustain ability/CS_PDFs/PlansReports/Reports/2013-2014-Annual-

Sustainability-Report.pdf

University of Calgary (2013). Sustainability Report 2012-2013. Retrieved from http://www.ucalgary.ca/files/er/2012-2013-SustainabilityReport.pdf

University of Gothenburg (2015). Sustainability Report 2014. Retrieved from

http://medarbetarportalen.gu.se/digitalAssets/1531/1531309_sustainab ility-report-2014-final.pdf

University of Liverpool (2014). Sustainability Annual Report 2013/14. Retrieved from https://www.liverpool.ac.uk/media/livacuk/sustainability/Annual,Repo rt,2015.pdf

University of Oxford (2015). Environmental Sustainability Report 2015. Retrieved from http://www.admin.ox.ac.uk/media/global/wwwadminoxacuk/localsites /estatesservices/documents/environment/environmentalsustainabilityre ports/sustain_report_2015_Final_v2.pdf

University of Virginia (2015. Sustainability Annual Report 2014-2015. Retrieved from http://sustainability.virginia.edu/docs/AnnualReport2014-2015.pdf

University of Queensland (2014). Annual Report 2014. Retrieved from http://www.uq.edu.au/about/docs/annualreport/annual-report14/UQAnnual-Report-2014.pdf

WCED (1987). Our Common Future. Oxford University Press, Oxford.

Delivered: 15.05.2019. Accepted: 18.12.2019. 